\title{
Correction to: Jasmonate Metabolism and Its Relationship with Abscisic Acid During Strawberry Fruit Development and Ripening
}

\author{
Adrián Garrido-Bigotes $^{1,2} \cdot$ Pablo M. Figueroa ${ }^{1}$ Carlos R. Figueroa $^{1}$
}

Published online: 30 October 2017

(C) Springer Science+Business Media, LLC 2017

\section{Correction to: J Plant Growth Regul}

DOI 10.1007/s00344-017-9710-x

The original version of this article unfortunately contained some mistakes in Table 1 and it is listed below:

1. Values in the color parameter "Hue $\left(\mathrm{h}^{\circ}\right)$ " are 45.21 and 35.46 instead 149.15 and 179.38 , respectively.

2. Some significance letters were incorrectly set: "b" instead " $a$ " in $L^{*}$ parameter, and " $a$ " in TAC must be placed in the greater value (i.e., 898.83).

3. At the first sentence of the footnote: "of the three different harvests" must be deleted, and "parameters" must be changed by "treatments".

The correct Table 1 is given here.

The online version of the original article can be found under doi:10.1007/s00344-017-9710-x.

Carlos R. Figueroa

cfigueroa@utalca.cl

1 Phytohormone Research Laboratory, Institute of Biological Sciences, University of Talca, Campus Talca, Avda. Lircay s/n, Casilla 747, Talca, Maule, Chile

2 Faculty of Forest Sciences, University of Concepción, Victoria 631, Casilla 160-C, Concepción, Bío Bío, Chile 
Table 1 Changes in firmness (N), color, and total anthocyanin content (TAC) after methyl jasmonate (MeJA) treatment in strawberry (Fragaria $\times$ ananassa $\mathrm{cv}$. Aromas) fruits

\begin{tabular}{|c|c|c|c|c|c|c|c|}
\hline \multirow[t]{2}{*}{ Treatment $^{\mathrm{a}}$} & \multirow[t]{2}{*}{ Firmness (N) } & \multicolumn{5}{|c|}{ Color parameters } & \multirow[t]{2}{*}{$\mathrm{TAC}^{\mathrm{b}}\left(\mu \mathrm{g} \mathrm{g}^{-1}\right)$} \\
\hline & & $\overline{\mathrm{L}^{*}}$ & $a^{*}$ & $\mathrm{~b}^{*}$ & Chroma & Hue $\left(h^{\circ}\right)$ & \\
\hline Control & $1.55 \pm 0.39 \mathrm{a}$ & $38.95 \pm 6.78 \mathrm{a}$ & $20.57 \pm 5.93 b$ & $25.19 \pm 4.69 a$ & $34.65 \pm 1.83 b$ & $45.21 \pm 7.62 \mathrm{a}$ & $377.72 \pm 50.76 b$ \\
\hline MeJA & $0.98 \pm 0.07 \mathrm{a}$ & $33.88 \pm 1.50 \mathrm{a}$ & $32.50 \pm 0.72 \mathrm{a}$ & $23.36 \pm 2.18 \mathrm{a}$ & $40.18 \pm 0.69 a$ & $35.46 \pm 3.06 \mathrm{a}$ & $898.83 \pm 160.18 \mathrm{a}$ \\
\hline
\end{tabular}

Data show mean values $\pm \mathrm{SE}(n=3)$. For each parameter, different letters indicate significant differences between treatments (LSD test, $\mathrm{p} \leq 0.05)$

${ }^{a}$ Treatment consisted in the application of $100 \mu \mathrm{M}$ MeJA or no MeJA (control) to strawberry fruits at white stage (W) during 5 days. See "Materials and Methods" section for details

${ }^{\mathrm{b}} \mathrm{TAC}$ were quantified as total $\mu \mathrm{g}$ of pelargonidin 3-glucoside equivalents per gram of fresh weight 